October - 2002

\title{
Redefining the Cost and Complexity of Library Services for Open and Distance Learning
}

\author{
Stephen Parnell \\ University of South Australia
}

\begin{abstract}
Although most universities profess a belief that libraries are a key element in learner support, the full cost and complexity of providing quality library services to support open and distance education tend to be underestimated. It is argued in this article that this underestimation, in part, may reflect a lack of appreciation by faculty and university administrators of the role libraries play in the (distance) learning process. Within libraries and the education sector at large, there is also tends to be a lack of recognition of what portion of the costs of access to libraries and information are borne by other elements within universities, by external organisations, and by individual students. Three fundamental questions addressed are: Why is it necessary to determine the role of libraries in supporting learning? Who meets these costs? How institutionally independent should access to library and information services be? While it is to be expected that the level of costs incurred by different institutions will vary as they meet the library service needs of those who study in different modes, there are pedagogical, ethical, and quality issues that must be considered if the same academic award is to be made.
\end{abstract}

Keywords: learner support; libraries; costing; cost analysis; quality; value judgment

\section{Redefining the Cost and Complexity of Library Services for Open and Distance Learning}

Attention given to identifying the full costs of library services as a component of quality learner support in open and distance education has been limited. While many of the elements covered here appear in the literature, no attempt has yet been identified to bring them together. Although there are studies examining overall higher education costs, particularly in the context of online education, information on costing libraries and their services relative to distance learning remains deficient. This is not entirely surprising given the complexity of the topic and the variation between institutions and how they view and resource library services. Although researchers have examined the costs of library services in a primarily on-campus environment (University of Newcastle, 2000) and direct costs of library service for distance learners (Cavanagh and Tucker, 1993), these and similar studies have not attempted to look beyond the direct costs often faced by an individual university's own library. Therefore, the purpose here is threefold: firstly, to consider libraries as an element in learner support; secondly, to consider less recognised costs associated with providing library and information services; and thirdly, to look at costs faced by individuals outside the physical precincts of universities when they attempt to access information and library services. Underlying themes referred to in 
this article are: the implicit reliance by open and distance education providers concerning the willingness and ability of students to access information through alternative avenues; and the willingness and appropriateness of other libraries supporting distance education students.

\section{The Value of Library Services}

Before looking at the costs faced by different providers and consumers of library services, it is worthwhile considering how these services support learning. This will indicate not just the range of activities that should be costed, but the extent to which libraries other than that of the parent university might meet the needs of distance learners. Services offered by reputable universities include:

- Twenty-four hour, seven days a week access to online library and information resources including library catalogues, citation and other indexes and full-text electronic journals

- Direct access by students to materials contained in general and research collections as well as to resources referred to in reading lists

- Assistance from professional librarians via email, telephone, fax and face-to-face

- Delivery of documents to students, both electronically and via courier or regular postal services

- Training and user education programs and resources via the Web, email, telephone, and face-to-face (including offshore)

- $\quad$ Filtered access to websites via subject and course based virtual libraries

- Facilitated access to the physical collections of other institutions

In short, university and college libraries play an integral role in a given university's total social and learning environment. A fundamental question that needs to be addressed then, is to what extent can these services be regarded as institution independent?

Unwin, Bolton and Stephens (1996) suggest that without ready access to this range of service, students face the risk that their learning experience will be unacceptably bound and controlled. Similarly, significant differences in accessibility of learning resources and experience across study modes should raise serious questions within universities about the appropriateness of offering the same academic award to those students without equivalent access to learning resources.

\section{Why Library Costs are Sometimes Overlooked}

Although library services are considered as an important element in learner support, and despite evidence that library users value the library more highly than many other university-supplied services (Tait 2000; Sell 1980, p. 312), few users assign dollar values to these services that are commensurate with the cost of the service (Kantor, 1995). Similarly, although surveys of guidelines on quality in online education report that students identify access to support services such as libraries as a central concern, some institutions make available to their distance education students only a fraction of the 
Parnell - Redefining the Cost and Complexity of Library Services for Open and Distance Learning

library resources and "other advantages" enjoyed by their on-campus student counterparts. It has been suggested that university administrators are often concerned about who will pay if the full costs of library and other services are made apparent (Bacsich and Ash, 1999). In such instances, it is difficult to avoid the conclusion that as long as the most important library resources are stated as being available online in some form, universities are likely to regard library services (an assumed standard requirement for creditable on-campus teaching), as having been met for the purposes of distance education as well (Garson, 1999).

A number of explanations account for why more realistic costs of quality library services for learners are sometimes overlooked. At the institutional level, where traditional services are also available from a physical library, there is a temptation to view library services to support open and distance education as simply "doing more of the same," with no significant cost implications attached. This simplistic view overlooks the need for additional infrastructure to ensure that distance learners off-campus have access to information and services comparable to that available to on-campus students. As libraries increasingly move from services that are traditional and reactionary, to services integrated creatively and thoughtfully into new technology-reliant curriculum initiatives, they will become more able to play an effective role in learner support (Adams, 1997). They do this by providing timely postal and electronic document delivery services, remote authentication and technology support, devising alternatives to traditional reserve collections, and by offering extended help desk hours that cover different time zones. These key contributions are not easily costed or even separated from other activities.

For many mixed mode institutions the percentage of distance education users is low as compared to the total student population. Furthermore, the evidence to date is that students who learn via distance education usually do not access the services of the home institution at the same rate as local students. At the University of South Australia, for example, less than thirty per cent of distance education students request assistance from the Library's Flexible Delivery Service. Figures from other Australian universities suggest rates of active use seldom approach fifty per cent. Of course this is a simplistic measure of use of library services that takes no account of the use students make of other information sources or libraries. Nor does it take into account anecdotal evidence from faculty that those students taking advantage of distance education library services generally achieve better results in assignments than those who do not. With the dropout rate for undergraduate distance education students generally higher than for those studying on-campus (Thompson, 1997) research is needed to establish whether better library support can help redress this imbalance.

The growth and influence of Internet based information is seen by some, as an alternative to the traditional library. When coupled with confusion stemming from the difference between offering resources and enhancing the learning experience, this adds to the factors that make it possible for institutions to both underestimate the costs of providing library services and accept less than optimal library services for their students studying offcampus. A less flattering explanation is that inadequate library services are an inevitable outcome of the belief that distance education is a way to reduce the costs of academic programs. This view tends to underestimate or ignore the significant infrastructure costs associated with quality library services. It also tends to discount the importance many students ascribe to access to library services and undervalues the role libraries and librarians can play in learning (Dillon, Gunawardena and Parker, 1992; Stephens and Unwin, 1997). It is a reflection that student concerns and behaviour are neither well understood nor regarded as strategic (Bacsich et al., 1999, p. 1). 
Libraries are not without blame either. There is sometimes a tendency to consider only core activities in costing support of distance education. Why is this so? A major factor is undoubtedly the difficulty associated with measuring the usage rates of library resources by students enrolled in open and distance education programs. This is not surprising when even services available on-campus prove difficult to measure. Costs per transaction figures in themselves have proven inadequate to establish annual costs per user, and such studies as exist show cost differences in providing university library services and facilities to external users ranging from two per cent to 125 per cent (Abels, Kantor and Saracevic, 1996; Infomax, 1994). Measuring the value of providing resources and services to meet student needs and the achievement of teaching objectives is even more problematic (Dervin, 1977).

\section{Partner or Parasite?}

The reason that universities are often able to offer their distance education library services "on the cheap," is that many off-campus students either make do with a limited range of resources, manage without a library altogether, or use someone else's library. Public libraries and the libraries of other higher education institutions bear the brunt of this use, an issue recognised in the concept of provider and victim libraries (Dugan, 1997). While many libraries are willing to take on the role of supporting students from other institutions, including those from interstate, inter-provincial, or overseas, costs are seldom apparent to the institution offering the academic program. The Infomax study (1994) concluded that it takes longer to answer reference enquiries from students from other institutions than for "home" users, but was unable to determine the reasons why this is so. It was suggested that this might be because students are less familiar with the host library than with their own, less likely to have participated in information literacy programs, and may ask more complex questions because they have already failed to fulfil their information requirements from information supplied to them as part of their course. This is not to suggest that host libraries are necessarily unwilling to take on a role in supporting distance learning; indeed the opposite is most often the case. Libraries have long recognised that they have much to gain in terms of resource sharing, networking, and collaborating on issues related to the provision of services to what are often mutual clients. Whichever is the case, one outcome at least remains the same: someone rather than the home institution must pay.

The mandate for public libraries to contribute to education is clear:

The public library should provide material in the appropriate media to support formal and informal learning processes. It should also help the user to make use of these learning resources effectively as well as providing facilities, which enable people to study.

(IFLA 2000 Section 1.3.1)

There is considerable representation in the literature examining the role of public libraries in assisting those engaged in open and distance learning. Slade and Kascus (1998) and Nankivell and Dalton (2000) are among those who have identified models of library services that indicate how different types of libraries can work together to meet the information needs of learners. The International Federation of Library Association (IFLA) Public Library Service Guidelines (2001) provides a range of examples of how public libraries in different countries provide resources of value to those studying offcampus. In one well-known project, partners from Sweden, the U.K., Ireland, Spain, and Austria are actively exploring the potential for using the Internet for distance learning in their public libraries. To date, the findings show that most people use the Internet in their 
public library for email and for finding information. They also reveal that those who use the Internet for educational purposes are often ordinary students who need to use computers when away from their own colleges (DERAL, 2000). With new technology coming into public libraries, librarians often see a need to take on additional roles beyond that of simple facilities provider, including the role of educator. Each of these new roles holds with it the potential to reduce demand by students on the libraries of their own institution. While formal agreements and cost sharing may be taken into account in costing programs, the costs of reciprocal services and those available through altruism are unlikely to be considered.

There is considerable potential for further convergence between the role of university and public libraries in distance education. Part of the push in this direction is coming from the public libraries themselves, but there is little doubt that universities also recognise the potential of public libraries. An example is the way in which universities often recommend public libraries to those students who do not enjoy ready access to the Internet. The interesting aspect of public library support arises when publicly funded libraries find that they are supporting the activities of institutions run for profit.

Of course it is not just public libraries that help meet the need of university students for library services. The Association of College and Research (ACRL) provides guidelines for library services to off-site students clearly stating that:

The home library is the primary source of materials; the off-campus librarian is the primary means of access and delivery [and] ... The parent institution is responsible for funding and appropriately meeting the information needs of its extended academic programs in support of their teaching and learning, and, when appropriate, research. This support should provide ready and equitable library service and learning resources to all students regardless of location (ACRL 1998).

Nevertheless, many of those studying through distance education are resident in cities that have a college or university library, and hence, see these as natural avenues to meet their information needs. Host libraries will often allow students of other institutions to use their collections in person and are often adopted by distance students as their information source of first resort (Stephens, 1998, p.139). Indeed, most will not even notice the presence of other students if they allow uncontrolled access to their buildings and have open access stacks. They are less likely to allow them to receive postal and electronic delivery services. As demand on collections grows and the volume of what is usually regarded as non-core work manifests itself, library service providers may be forced to reconsider the nature and extent of their generosity. If visitor use of key resources, such as computers and reserve collections, becomes noticeable, the library's major client groups may also exert pressure to restrict access to these same resources. As libraries increase their reliance on licensed electronic resources, the ability for anyone other than registered staff and students of the "home" university to gain access to subscription databases and electronic journals is likely to be reduced, thereby revealing some of the current hidden costs of library services. This should become especially apparent as disenfranchised students are forced to utilise the resources of their own institution.

Distance education students, compared to their on-campus counterparts, may be less well served in the area of information literacy. Those who believe that the same assistance and resources necessary for students studying on-campus should be provided to students studying off-campus argue that information literacy resources and services must be 
developed to meet the particular needs of those students studying off-campus. If arrangements are made by the host library to enable distance learners to participate in their user education activities, this often hides both the need for such services as well as a potential cost in program development or delivery for the home institution.

The issues facing academic libraries are covered in Parnell (1996). What is of interest here is that "host" libraries may provide assistance to students without an underlying awareness or appreciation of course objectives and requirements. While this reduces the cost of information provision by the distance education provider, it does raise interesting questions as to how far institutional teaching programs and assessment can be quarantined from the external information environment. There is scope for more research to determine as to whether the value of individual library information services is the same if offered by someone else.

This is, of course, a simplistic picture of what libraries can and actually do for students. There are many innovative partnerships between different institutions and libraries of all types that suggest something of the range and complexity of the costing issue. This does not, however, alter the underlying argument presented here, namely such partnerships are seldom considered or costed in distance education programs.

\section{Transferring Costs to Students}

There is a tacit (and sometimes explicit) acceptance by many institutions that students can and should meet some or all costs of the services they use. A number of leading distance providers expect students to contribute towards meeting the cost of postage and photocopying carried out on their behalf by their libraries, even though electronic services are often available without charge. Although fees charged may not necessarily be high, they continue to be identified by students as a barrier to use of library services, confirming the work of Bottomley and Calvert (1993, p. 34) that even those students who acknowledge the value of library services are often unwilling to pay. As more of a given university's teaching and learning goes online and the quality of information freely available via the Internet expands, the wisdom of charging for library services in an environment where institutions compete for students is increasingly questionable. The need to adequately cost such services remains.

McGivney (1993, pp. 17-18) identifies time and cost as the main situational barriers to participation in formal learning. When an institution moves to online education, one of the most common costs borne by students is the transfer that occurs when the student rather than the institution pays to print and post instructional materials. Rumble (1997, p. 117) identified the risk that third generation (electronic access) distance education systems will transfer costs to students, and speculates that they may also change the nature of the cost borne by students from time to money or vice versa. There are two dimensions to the largely over looked issue of the cost in time to students that needs to be devoted to information finding activities. This is the time that students could have been better spent evaluating, analysing, and synthesising information, whether provided to them or self discovered, and time that could have been devoted to some other activity entirely. The issue, however, is not clear-cut, with many educators arguing that the ability to identify and locate relevant information is itself part of the learning process. While libraries extol the virtues of the e-library as an alternative to visiting library buildings, some students accustomed to use of libraries in person already regard lack of browsing and personal assistance from library staff as a barrier to finding information in the online environment. Conversely, some students find that transference of the cost from one of time to direct financial expenditure imposes an unacceptable financial burden. 
Parnell - Redefining the Cost and Complexity of Library Services for Open and Distance Learning

Although many online courses now rely heavily upon readings available electronically from libraries, the survey instrument used as part of the UK networked learning study did not attempt to estimate use of the telephone specifically to access to University resources (Bacsich et al., 1999). Nor did it ask about time or money spent on use of library and other information services. While use of other libraries may be free, this is not always the case, particularly for those enrolled in trans-national undergraduate programs (Back, Cheng and Lam, 1993; Parnell and Stevens, 1999). Institutions similarly often fail to quantify costs that are generally absorbed into larger budgets and therefore cannot be easily attributed to a particular activity. Library staff members running training sessions offshore provide another example. While travel costs are easily identified, the cost of time taken up by travel is less likely to be fully accounted for.

\section{Back Beyond the Digital Library}

While it is not surprising that universities and their libraries currently appear to be focusing on the online environment, it is important not to overlook the value of the substantial print collections held by libraries in learner support. Nor should other library services that value-add to the learning process, such as reference and instructional services, be overlooked. Figures for the year 2000, for library services for the University of South Australia's distance education students, and those of its contracted service for Open Learning Australia, show requests for books continue to match those for articles. This is particularly the case for postgraduate students where much specialised research material is only available in print. This is an issue for those studying offshore as well. Surveys of the same university's students in Hong Kong, Singapore, Taipei and elsewhere confirm both the need for and the difficulties students experience in locating and gaining access to printed resources. Little consideration seems to have been given to comparing costs associated with providing access to information resources to individual students, compared to that of supplying information to them in print, although the importance of access to support material is recognised in work on a business model for the e-University (PricewaterhouseCoopers, 2001).

Despite this role for print, it remains true that for many distance education providers, technology is changing staff and student expectations of what the library should be and should offer. While some academic staff see this as an opportunity to expand and exploit the range of information available to distance education students, others appear to be retreating to reliance upon small discrete packages of selected readings supplemented by a recommendation to "find it on the Internet." It is also apparent that the World Wide Web is altering the current balance between libraries and teaching faculty as information providers, particularly as faculty involved in online education often incorporate direct links to "library" resources within individual courses. While many of these electronic resources are available only as part of an expensive library subscription, developments such as these obscure the value as well as the costs of a comprehensive library service.

Another reason is suggested for institutions failing to identify the full costs of library services. The argument is that if a given university must pay the costs required to provide library services for its off-campus students, it would be at the expense of the on-campus library program (Kascus and Aguilar 1997, p. 33). Even under this model it is debatable whether open and distance learners would receive services equivalent to that of oncampus students as far as immediacy of access and availability of materials is concerned. The disparity in opportunity to learn skills through one-on-one interactions with a librarian during the research process would still remain. It is intriguing to speculate on how many universities could meet the load if all eligible users actually tried to take advantage of existing learner support services. 


\section{Diverse Users and Average Costs: A recipe for confusion}

The costs of distance education are likely to be underestimated unless client groups and services are clearly defined. For dual mode institutions, among the most intractable of these questions of definition in is establishing which activities and students are to be included. They are likely to have students who live many kilometres from the "home" university, but are nonetheless enrolled as "internal students." Conversely, students who live within walking distance might be enrolled entirely in off-campus or fully online programs. Such institutions are a feature of the Australian education environment and are regarded as a successful (Davies and Stacey, 1998, p. 705). It is also increasingly the case that students enrol in diverse courses with multiple institutions. Separating out costs is all but impossible in this context.

Although those who study via distance education do not access the services of the home institution at the same rate as local students, there is evidence that distance learners who use library services require more time from library staff on a per capita basis than those who can visit the library in person. This is particularly the case for those undertaking higher degrees and for those for whom English is a second language. For this latter group of students, particularly overseas residents, western expectations of independent study can be as foreign as the language. To provide effective library services to such students is time consuming, costly, and complex. It is also clear that it is more expensive to service postgraduate students than undergraduates (Cavanagh and Tucker, 1993, p. 67). As institutions increase their off-campus offerings of higher degree programmes, the costs of meeting user needs will rise. This is because, in part, key traditional service strategies, such as library closed reserve collections, do not work well for research level courses.

For institutions with students residing in other countries, there are other factors to consider. Conducting training sessions offshore that parallel on-campus academic teaching programmes represents a considerable investment in time and money on the part of a library; it also provides a clear indication of its commitment to providing a comprehensive range of services to students regardless of mode of study or location. While expensive, training such as that provided by the University of South Australia to its students in Hong Kong, Singapore, and Bangkok has evoked favourable responses from both local agents and students, in part because it is viewed as another measure of equivalence with services available to Australian students (Parnell and Stevens, 1999). Costs include travel, accommodation, renting training facilities, and finding replacement staff for the normal on-campus staff conducting the training.

\section{Library Infrastructure: Overlooked and underestimated?}

Apportioning capital and running costs can be as much of a challenge as determining which avenues students use to find information. Even minor items such as library hours need to be considered. Another consideration of this is how much space of a given building should be attributed to those enrolled as off-campus students. If the opportunity is available, many off-campus students will visit the physical library and indeed this might even be a requirement during residential schools. Traditional costing systems allocate indirect costs to the different resources or user groups on the basis of volume measures such as the number of journals purchased or number of staff employed. The limitation with this approach is that many indirect costs such as research and 
development and marketing are independent of volume measures (Ellis-Newman, 1998, p. 376).

Significant costs may be incurred in determining, facilitating, or shoring up interdependencies between different parts of an institution. An example of such a need in the library context is provided when academic departments either overlook the value to their students of access to libraries, or too readily accept, at face value, assurances that a partner institution will provide library services equivalent to those enjoyed by students able to access their home institution's library. There is no evidence to suggest that universities offering courses offshore and franchising their programs to other organisations for local support undertake any systematic study of the willingness and capacity of other libraries to support their students as standard practice. For the many universities that are increasingly choosing partnership or twinning models to meet student demand for face-to-face contact, this is a significant oversight.

\section{Hidden Costs of Libraries in Distance Education}

Under the original UK Open University course model, the majority of students were assumed not to require a library service from their own university, an assumption based in part on the belief that the strong public library system in that country could meet their needs (Carty and Stark, 1996, p. 305). Although this view is no longer uniformly held, and despite the increasing acceptance and availability of information delivered electronically, the role of the public library network is still viewed as essential to the success of the e-University (SCONUL, 2001).

While it is essential that libraries identify the real costs of their services, they also need to be conscious of the limitations of costing methodologies that concentrate on what is being done rather than what can or should be done. There is also a need to be aware that such institution-centric studies do not take into account costs borne by outside organisations and individuals. There is a danger that in concentrating on the costs of current services in isolation, the relationship between cost and quality and range of service will be overlooked. The risk of determining the "cost of everything and the value of nothing" is real (Bacsich and Ash, 1999). In such an environment, efforts to reduce or contain costs in one sector may simply transfer costs to another part of the delivery or support chain.

Table 1. Commonly costed items

\begin{tabular}{|l|l|}
\hline Equipment and Resources & Staffing Costs \\
\hline Computer system running costs & Find and post book \\
Books in collection & Find, copy and post or scan article \\
Electronic journals and databases & Loan item \\
Printing guides and handouts & Information en quiry \\
Communication & Literature search \\
(fax, post, telecommunication) & Training and user education classes \\
& (on-campus, off-campus, and offshore) \\
& Photocopy service \\
& Re-shelve item \\
& Learning resource development \\
& Administration \\
\hline
\end{tabular}


Broader institutional costs including capital, depreciation, and running costs associated with library buildings are widely recognised, though less likely to be attributed in any estimation of the costs of library services. There are many other elements that could be included. The University of Newcastle study (2000) examining activity based costing provides detailed coverage of these. In distinguishing use of resources within buildings for those who study in mixed or dual modes, there are significant difficulties.

Many activities undertaken by library staff in support of student learning escape notice because they are outside the range of activities normally attributed to librarians. Rumble (1999) concluded that the biggest and least costed element of online learning is learner support. While he interpreted this primarily in terms of the role of tutors within the Open University, the case is also arguable for librarians. One aspect of this overlooked activity for librarians is their role in counselling. A major study in costing activities within Australian higher education institutions (Robertson,1998, p. 40) recognised the importance of counselling as a teaching and learning activity, but considers this only within the context of academic programs, rather than within other sectors of the institution such as the library. Certainly time spent on counselling activities within some university libraries is sufficiently great and differentiated from the normal reference interview to warrant recording separately. A possible explanation for the popularity of this un-marketed service is that library staff are sometimes more immediately accessible than their academic colleagues. While it can be argued that the financial cost of this service will be captured within the item of library staff salaries, this is a poor reflection of either the value of the library service or the costs of providing individual academic programs. The hidden costs of library support for open and distance learning are shown in Table 2.

Table 2. The hidden costs of a distance education library service

\begin{tabular}{|l|l|l|}
\hline Home library costs & Cost to external library & Cost to student \\
\hline $\begin{array}{l}\text { Collaboration with } \\
\text { academic staff - resource } \\
\text { selection and development }\end{array}$ & $\begin{array}{l}\text { Opportunity costs to own } \\
\text { primary clientele }\end{array}$ & Internet connection \\
\hline $\begin{array}{l}\text { Collaboration with } \\
\text { academic staff - response to } \\
\text { student enquiries }\end{array}$ & & Telephone connection \\
\hline $\begin{array}{l}\text { Counselling role for } \\
\text { students }\end{array}$ & $\begin{array}{l}\text { Competition from students of } \\
\text { other institutions }\end{array}$ & Printer Consumables \\
\hline $\begin{array}{l}\text { Collaboration with other } \\
\text { service units }\end{array}$ & & Registration/ service fee \\
\hline $\begin{array}{l}\text { Extended licences for } \\
\text { remote users }\end{array}$ & $\begin{array}{l}\text { Cost of multiple policies and } \\
\text { procedures }\end{array}$ & Computer purchase / hire \\
\hline Authentication work & & Postage \\
\hline $\begin{array}{l}\text { Establishment of separate } \\
\text { services }\end{array}$ & $\begin{array}{l}\text { Establishment of separate } \\
\text { services }\end{array}$ & $\begin{array}{l}\text { Confusion over availability } \\
\text { of services }\end{array}$ \\
\hline
\end{tabular}

The whole issue of costs associated with libraries in distance education is further complicated because many faculty and students tend to view the Internet as either an alternative to the library, or as the same thing. This view can only strengthen as universities seek the economic advantage and pedagogic integrity that appear possible from blurring the boundaries between on-campus, distance, dual-mixed mode and online education into one of flexible delivery. According to one survey, over 80 per cent of new students studying on-campus used the Internet to support their studies (UCLA, 2000, p.11) and students studying offshore through the University of South Australia in 1999 and 2000 identified the Internet as the most frequently used information source (University of South Australia Library, 2001). The changing balance between costs to 
students' use of the Internet, and the effects of student Internet usage on costs of a distance education library service, has yet to be fully explored.

While thus far emphasis has been on the financial costs of library services in distance education, in a climate of greater cost consciousness, we also need to remember to ask whether an increased urgency and capacity to measure "not just how often something is used, but by whom," will aid or divert teaching. At a time of emphasis upon cost effectiveness and cost cutting, there is an understandable temptation for libraries to direct their resources into more frequently used (full-text) services at the expense of less frequently used specialised services. Unless it is an outcome of careful consideration of the underlying educational objectives of the institution, this is to be resisted.

\section{Conclusion: Overlooked and under costed}

There appears, at times, to be a lack of appreciation within the higher education sector of the extent to which the costs of access to library services are borne by other organisational elements, external organisations, and by individual students. The contribution that library services play in students' university learning experience as a whole also tends to be under valued (Stephens and Unwin, 1997; Dority and Garnar, 1999). In an environment in which universities are increasingly looking to outsource services, including aspects of library services, it is important to know what different services cost in order to establish how these relate to total education costs for students as well as for the universities.

There is a strong case for arguing that boundaries must be established that outline the relationship between the complexity of the information environment and where costs actually lie. Although it is argued here that the hidden costs of library services effectively allow institutions to offer distance education programs "on the cheap," this viewpoint should not be taken in a pejorative sense. Nor should it be imagined that it is only the needs of distance education students that are often met outside the provisions of the institution in which they are enrolled. Nonetheless, many academic institutions that offer distance learning take advantage of existing infrastructure and assets without formulating a clear understanding of the role libraries can play in the learning process and in the development of information literate students.

The dearth of relevant studies in the literature suggests that the full costs of providing quality library services to support programs offered by universities through distance education are either overlooked or underestimated by libraries and their parent institutions. There are three inter-related reasons behind this oversight. The first is that in many instances, faculty and university administrators fail to fully understand the complex role library services play in the distance education process. The second reason is an outcome of reliance by learners upon other libraries. While this is well recognised by librarians, this is less likely to be the case by university administrators as a whole. The third and perhaps the most disturbing reason, is the lack of support for the view that if distance education students are to receive the same degree or award as their on-campus counterparts, the same services and resources considered to be an integral part of the education process for on-campus students, must also be made available. While there have been dramatic improvements in the capacity for educational institutions to deliver information and services electronically, services available to those studying through distance education are often not as comprehensive as for those students able to visit a large academic library in person. Research that is currently underway into the costs of 
higher education needs to be extended to include the full costs borne by institutions, their students, and other libraries, in meeting the information needs of distance learners. Given the many institutional variables that need to be considered this will not be an easy task.

\section{References}

Abels, E., Kantor, P., and Saracevic, T. (1996). Studying the cost and value of library and information services: Applying functional cost analysis to the library in transition. Journal of the American Society for Information Science 47(3), 217 27

ACRL (1998). Guidelines for distance learning library services. Association of College and Research Libraries. Retrieved 21 August 2001 from: http://www.ala.org/acrl/guides/distlrng.html

Adams, C. (1997). The Future of Library Services for Distance Education. JLSDE 1(1). Retrieved July 7, 2002 from: http://www.westga.edu/ library/jlsde/vol1/1/CAdams.html

Back, D., Cheng, C., and Lam, M. (1993). Offshore business degree: the economics of student support. In Economics of distance education: 7th Annual Conference of the Asian Association of Open Universities (November, 21 - 25) Open Learning Institute of Hong Kong.

Bacsich, P., and Ash, C. (1999). The hidden costs of networked learning - The impact of a costing framework on educational practice. Paper presented to the 1999 ASCILITE conference, Queensland University of Technology: Brisbane, Australia.

Bacsich, P. (1999). The costs of networked learning. Sheffield Hallam University, UK. Retrieved July 5, 2001 from: http://www.shu.ac.uk/virtual_campus/cnl/

Bottomley, J., and Calvert, J. (1993). Dimensions of Value: Estimating the benefits of higher and distance education programs. In Economics of distance education: 7th Annual Conference, Asian Association of Open Universities (November, 21 - 25) Open Learning Institute of Hong Kong.

Carty, J., and Stark, I. (1996). Towards a Strategy for Supporting Distance-Learning Students through Networked Access to Information: Issues and Challenges in Preparing To Support the Doctorate in Education. Education for Information, 14(4) $305-314$.

Cavanagh, A. K., and Tucker, J. (1993). Costing of Off-Campus Library Services. Proceedings of the sixth off-campus library services conference. Kansas City, KA. (October 6-8), 59 - 72.

Davies, G., and Stacey, E. (1998). Virtual universities: are dual mode universities the solution? In 28th Annual Frontiers in Education Conference. Tempe, AZ. (November 4-7), 705 - 710.

DERAL (2001). Distance Education in Rural Areas via Libraries website. Retrieved May 21, 2002 from: http://www.infc.ulst.ac.uk/ adrian/deral/home.html 
Dervin, B. (1977). Useful Theory for Librarianship: Communication not information. Drexel Library Quarterly 13, 16 - 32.

Dillon, C., Gunawardena, C., and Parker, R. (1992). An evaluation of learner support services in a distance education system, Distance Education 13(1), 29 - 45.

Dority, K., and Garnar, M. (1999). The electronic global library of Jones International University Advances in Library Administration and Organization 17, 93 - 107.

Dugan, R. E., and Hernon, P. (1997). Distance education: Provider and victim libraries. Journal of Academic Librarianship 23(4), 315 - 324.

Ellis-Newman, J., and Robinson, P. (1998). The cost of library services: Activity-based costing in an Australian academic library. Journal of Academic Librarianship 24(5), $373-92$.

Garson, G. D. (1999). The Role of Technology in Quality Education. Retrieved August 21, 2001 from: http://hcl.chass.ncsu.edu/sscore/garson2.htm

Infomax (1994). Unison external use cost survey: a report. Sydney: Macquarie University.

IFLA (2001). The Public Library Service: IFLA / UNESCO guidelines for development. Saur, Munchen. Retrieved August 21, 2001 from: http://www.ifla.org/VII/s8/proj/publ97.pdf

Jones, D. (2000). Emergent development and the virtual university. Retrieved August 21, 2001 from: http://cq-pan.cqu.edu.au/davidjones/Publications/Papers_and_Books/Learning_2000

Kantor, P. B. (1995). Studying the Cost and Value of Library Services: Final report. Technical Report APLAB/94-3/1,2,3,4. ERIC Document ED382206

Kascus, M., and Aguilar, W. (1988). Providing Library Support to Off-campus Programs. College and Research Libraries 49(1), 29 - 37.

McGivney, V. (1993). Participation and non-participation: A review of the literature. In R. Edwards, S. Sieminski and D. Zeldins (Eds.) Adult learners, education and training. London: Routledge.

Nankivell, C., and Dalton, P. (2000). Models for Working Together: Lifelong learners, library cross-use and collaborative solutions. In P. Brophy, S. Fisher, and Z. Clarke (Eds.) Libraries without Walls 3: the delivery of library services to distant users. London: Library Association, pp. 49-59.

Parnell, S. (1996). Literature searches and distance education: Whose problem? Occasional Papers in Open and Distance Learning 20. Open Learning Institute: Charles Sturt University.

Parnell, S., and Stevens, A. (1999). Report on library services for students and staff of the University of South Australia: Singapore and Hong Kong. University of South Australia 
PricewaterhouseCoopers (2000). Business model for the e-University. Retrieved August 21, 2001 from: http://www.hefce.ac.uk/Pubs/HEFCE/2000/00_44.htm

Robertson, S. (1998). Costing methodology for use within Australian higher education institutions. Canberra: Ernst \& Young. Retrieved August 21, 2001 from: http://www.detya.gov.au/archive/highered/otherpub/costme2.pdf

Rumble, G. (1997). The costs and economics of open and distance learning. London: Kogan Page.

Rumble, G. (1999). The Costs of Open Learning: What have we learnt?' In FLISH 99 1999 conference on flexible learning on the information superhighway. Sheffield Hallam University, May. Retrieved August 21, 2001 from: http://www.shu.ac.uk/flish/rumblep.htm

SCONUL - Standing Committee of National and University Libraries (2001). Information support issues for the e-University: a discussion paper: Appendix. Retrieved September 26, 2002 from: http://www.sconul.ac.uk/discppr.doc

Sell, B. (1980). An evaluative, holistic and user-oriented approach to assessing and monitoring effectiveness of the academic library in its setting. In N. K. Kaske (Ed.) Library Effectiveness: a state of the art. Washington: American Library Association, 296 - 336.

Slade, A., and Kascus, M. (1998). An international comparison of library services for distance learning. In P. S. Thomas and M. Jones (Comps.) The Eighth OffCampus Library Services Conference Proceedings. Providence, RI. (April 22-24) Mount Pleasant, MI: Central Michigan University Press. 280 - 281.

Stephens, K., and Unwin, L. (1997). The Heart of the Matter: Libraries, Distance Education and Independent Thinking. JSLDE, 1(1). Retrieved August 22, 2001 from: http://www.westga.edu/ library/jlsde/jlsde1.1.html

Stephens, K. (1998). Library experiences of postgraduate distance learning students, In P. Brophy, S. Fisher, and Z. Clarke (Eds.) Libraries Without Walls 2: the delivery of library services to distant users. London: Library Association. 122 - 142.

Tait, A (2000). Planning student support for open and distance learning. Open learning, 15(3) $287-299$.

Thompson, E. (1997). Distance education dropout: What can we do? In R. Pospisil and R. Willcoxson. Learning through teaching: Proceedings of the 6th Annual Teaching Learning Forum, Murdoch University. Retrieved August 30, 2001 from: http://cleo.murdoch.edu.au/asu/pubs/tlf/tlf97/thom324.html

UCLA Centre for Communication Policy (2000). The UCLA Internet report: Surveying the digital future. Retrieved August 22, 2001 from: http://ccp.ucla.edu/uclainternet.pdf

University of Newcastle (2000). Activity Based Costing: A Study to develop a costing methodology for Library and Information Technology Activities for the Australian Higher Education Sector. Canberra: Department of Education, 
Training and Youth Affairs. Retrieved September 30, 2002 from: http://www.dest.gov.au/highered/otherpub/libraries/libraries.pdf

Unwin, L., Bolton, N., and Stephens, K. (1997). The Role of the Library in Distance Learning, Final Report. London: British Library.

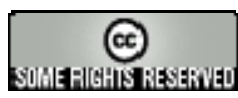

